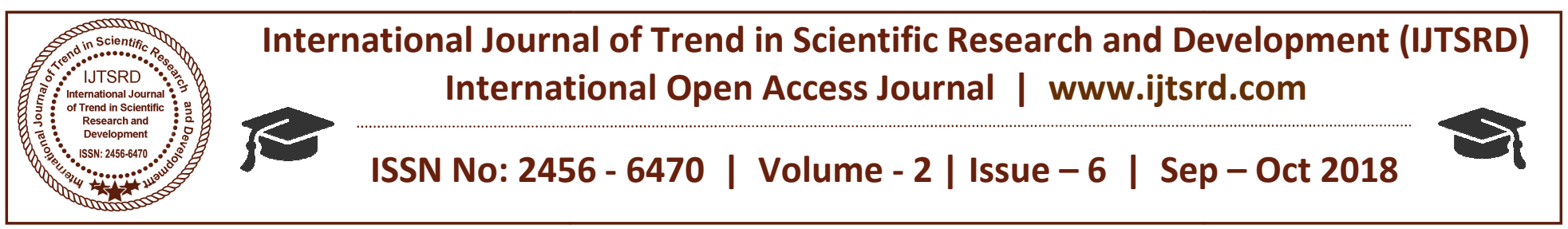

\title{
Capital Market Instruments in India - A Profile
}

\author{
Prasanta Kumar Dey \\ Associate Professor, Department of Commerce, Sir Gurudas Mahavidyalaya, \\ Ultadanga, Kolkata, West Bengal, India
}

\begin{abstract}
To have an idea on Capital Market, it is very much essential to know important instruments inter alia used in primary and secondary segments of capital market. Capital market instruments are those instruments which are used by the corporate entities for raising medium and long term funds from the capital market. Capital market instruments used for market trade are of two types - direct capital market instruments and indirect capital market instruments. The direct instruments are equity / ordinary shares, preference shares, debentures / bonds / notes and innovative debt instruments. Among these, securities like equity and preference shares are ownership instruments while debentures / bonds / notes and innovative debt instruments are creditor-ship securities. Derivative instruments and others are the indirect instruments. This article contains a profile on various concepts and terminologies relating to instruments used in the capital market of India. At first, various conventional instruments of capital market have been discussed. Then, some important concepts and terminologies relating to nonconventional instruments for trading on Indian bourses have been discussed.
\end{abstract}

Keywords: Bonds, Debentures, Derivatives, Funds, Securities, Shares

\section{INTRODUCTION}

Capital market is a sine-quo-non for speedy growth and sustainable development of a country's economy and India is no exception to it. Capital market is a part of financial market where medium and long term securities like stocks and bonds are traded. From here, the business enterprises like companies and governments can raise medium and long-term funds. The Indian Equity Markets and the Indian Debt markets together form the Indian Capital market. It is different from money market where monetary assets such as commercial paper, certificate of deposits, treasury bills etc. which mature within a year are traded. Capital market helps to channel the wealth of savers who can put it to the long term productive users such as companies and governments.

Capital market instruments used for market trade include shares, debentures, bonds, foreign exchange, fixed deposits, derivatives etc. As they involve equity and debt securities, the instruments are also called securities and the market is referred to as securities market. A derivative is an instrument whose value is derived from the value of one or more underlying assets, which can be commodities, precious metals, currency, bonds, stocks, stocks indices etc. Four most common examples of derivative instruments are Forwards, Futures, Options and Swaps. Capital market instruments in India can be again classified into three categories: Pure, Hybrid and Derivatives. The pure instruments are equity shares, preference shares, debentures and bonds which are issued with the basic characteristics without mixing the features of other instruments are called pure instrument. The hybrid instruments are instruments which are created by combining the features of equity, preference and bond, such as convertible preference shares, non-convertible debentures with equity warrant, partly convertible debentures, secured premium notes etc. The derivative instrument is a financial instrument which derives its value from the value of some other financial instruments or variables.

Capital market instruments - Savings of investors are linked to investments through a range of complex financial products generally called capital market instruments include shares, debentures, bonds or other marketable securities of a like nature issued by any incorporated company or body corporate, derivatives, 
units issued by any collective investment scheme to the investors in such schemes, any certificate or instrument (by whatever name called) issued to an investor by any issuer being a special purpose distinct entity which possesses any debt or receivable, including mortgage debt, assigned to such entity, and acknowledging beneficial interest of such investor in such debt or receivable, including mortgage debt, as the case may be; government securities and such other instruments as may be declared by the Central Government to be securities. This section of the article contains short discussion on various instruments relating to the Indian capital market in brief as follows -

1. Equity / Ordinary shares - The ownership capital of a company is divided into a number of indivisible units of a fixed amount. These units are known as shares. Thus, if the share capital of a company is Rs. 5 lakh divided into 50,000 units of Rs. 10, each unit of Rs. 10 shall be called a share of the company. As per Section 85 (2) of the Indian Companies Act, 1956 equity shares are those shares which are not preference shares. Again, as per Section 43 of the Companies Act 2013, the share capital of a company limited by shares shall be of two kinds, namely (a) equity share capital and (b) preference share capital. Here, equity share capital with reference to any company limited by shares means all share capital which is not preference share capital. In other words, shares which do not enjoy any preferential right in the matter of payment of dividend or repayment of capital are known as equity shares. Equity share may be issued with voting rights or with differential rights as to dividend, voting or otherwise in accordance with such rules as may be prescribed. Equity shares are also known as ordinary shares and typically have a par / face value and the most popular denomination is Rs. 10. However, companies are permitted to issue shares of any par value of not less than Re. 1 and in multiples of Re. 1. The price at which the equity / ordinary shares are issued is the issue price. The issue price for new companies particularly without any profit track-record is at par which is equal to the face value. Issue price may be higher for existing profit making companies, the difference / excess being the share premium. Equity shares may also be issued by the company at discount which is lower than face value. In case of existing company, the book value of ordinary shares refers to the paid up capital plus reserves and surplus (net worth) divided by the number of outstanding shares. The price at which equity shares are traded in the stock market is their market value. However, the market value of unlisted / rarely traded shares is not available. Few variants of the equity shares are discussed below:

A. Bonus shares - As per Section 65 of the Companies Act 2013, a company may issue fully paid-up equity shares as bonus to its members, in any manner whatsoever, out of (i) its free reserves; (ii) the securities premium account; or (iii) the capital redemption reserve account provided that no issue of bonus shares shall be made by capitalizing reserves created by the revaluation of assets. The bonus shares shall not be issued in lieu of dividend.

B. Right shares - Right shares are those shares which are issued after the original issue of shares but having an inherent right of the existing shareholders to subscribe to these shares in proportion to their holding. Such shares must be offered to the existing equity shareholders on pro rata basis. The offer of this type of shares shall be made in the form of a notice giving the particulars of shares offered and within a time not less than 15 days from the date of the offer for acceptance of such offer. These shares can also be issued to the new members when the existing shareholders do not accept the offer within a period of 15 days or more. Usually, these shares are issued among the existing shareholders at a concessional rate. But before issuing such shares the public company must follow the SEBI (Securities and Exchange Board of India) Guidelines in this regard.

C. Sweat equity shares - A company may issue sweat equity shares of a class of shares already issued, if the following conditions are fulfilled, namely - (a) the issue is authorized by a special resolution passed by the company; (b) the resolution specifies the number of shares, the current market price, consideration, if any, and the class or classes of directors or employees to whom such equity shares are to be issued; (c) not less than one year has, at the date of such issue, elapsed since the date on which the company had commenced business; and $(d)$ where the equity shares of the company are listed on a recognized stock exchange, the sweat equity shares are issued in accordance with the regulations made by the Securities and Exchange Board in this behalf and if they are not so listed, the sweat equity shares are issued in accordance with such rules as may be 
prescribed. The rights, limitations, restrictions and provisions as are for the time being applicable to equity shares shall be applicable to the sweat equity shares issued under this section and the holders of such shares shall rank pari passu with other equity shareholders.

D. Share Warrant - A share warrant is a document issued by the company under its common seal, stating that its bearer is entitled to the shares or stock specified therein. A warrant holder acquires only the right / option but he / she have no obligation to acquire the equity shares. Warrants are usually issued along with other instruments or can be issued separately. Share warrants are negotiable instruments. They are transferable by mere delivery without registration of transfer. Warrants can be issued in two forms viz.: (1) Detachable warrant and (2) Non-detachable warrant.

2. Preference Shares - Preference share is a unique type of long-term capital market instrument and it combines some of the features of equity shares as well as some of debentures. As a hybrid form of financing instrument, it is similar to debentures in so far as it: (i) carries a fixed / stated rate of dividend (ii) ranks higher than equity as a claimant to the income / assets (iii) normally does not have voting rights and (iv) does not have a share in residual earnings / assets. It also partakes some of the attributes of equity capital, namely, (i) dividend on preference capital is paid out of divisible / after tax profit, that is, it is not tax deductible (ii) payment of preference dividend depends on the discretion of the management, that is, it is not an obligatory payment, and nonpayment does not force insolvency / liquidation and (iii) irredeemable types of preference shares have no fixed maturity date. There are several types of preference shares discussed as below:

A. Participating preference shares - This kind of shares are entitled to get regular dividend at fixed rate. Moreover, they have a right for surplus of the company beyond a certain limit. These shareholders are also allowed to share in surplus assets of the company being wound up.

B. Non-participating preference shares - The holders of this type of shares are not entitled to share the additional benefits that are happened in case of participating preference shares.

C. Cumulative preference shares - For such type of shares, the dividend not paid in a particular year due to non-availability of profit, the shareholders are entitled to get arrear dividend out of profit of the subsequent year or years.

D. Non-cumulative preference shares - But, the holders of non-cumulative preference shares are not entitled to get arrear dividend out of profit of subsequent year or years in case of nonavailability of profit to declare dividend in any year.

E. Convertible preference shares - Such shares can be converted to equity shares at the option of the holder. Hence, these shares are also known as quasi equity shares. Conversion of preference shares in to bonds or debentures is permitted if company wishes. The conversion feature makes preference shares more acceptable to investors. Even though the market for preference shares is not good at a point of time, the convertibility will make it attractive.

F. Non-convertible preferable shares - The preference shares without the right of conversion are called non-convertible preference shares.

G. Redeemable preference shares - A company may issue redeemable preference shares to avoid fixed liability of payment, to increase the earnings of equity shares and to make the capital structure simple or such other reasons. These shares are redeemed after a given period. Such shares can be repaid by the company on certain conditions, viz.: (i) the shares must be fully paid up; (ii) it must be redeemed either out of profit or out of reserve fund for the purpose; (iii) the premium must be paid if any.

H. Irredeemable preference shares - A company may issue irredeemable preference shares and these shares are not redeemable except on the liquidation of the company.

3. Debentures - Debenture is an instrument under seal evidencing debt. The essence of debenture is admission of indebtedness. It is a debt instrument issued by a company with a promise to pay interest and repay the principal on maturity. Debentures represent creditor ship securities and debenture-holders are long term creditors of the company. As a secured instrument, it is a promise to pay interest and repay principal at stipulated times. In contrast to equity capital, which is a variable income security (i.e. in respect of dividend), the debentures are fixed income (i.e. in respect of interest) security. Sec 2 (12) of the Companies Act, 1956 states that debenture includes debenture stock, bonds and other securities of a company and Sec 2(30) of the 
Companies Act, 2013, debenturell includes debenture stock, bonds or any other instrument of a company evidencing a debt, whether constituting a charge on the assets of the company or not. It is customary to appoint a trustee, usually an investment bank to protect the interests of the debenture holders. This is necessary as debenture deed would specify the rights of the debenture holders and the obligations of the company. There are several types of debentures discussed as below:

A. Bearer Debentures - Bearer debentures are payable to bearer and are transferable by mere delivery. Interest coupons are attached to the certificate or bond. As interest date approaches, the appropriate coupon is clipped off by the holder of the bond and deposited in his bank for collection. The bank may forward it to the fiscal agent of the company and proceeds are collected. Such bonds are negotiable by delivery.

B. Registered Debentures - In the case of registered debentures, the name and address of the holder and date of registration are entered in a book kept by the company. The holder of such a debenture bond has nothing to do except to wait for interest payment which is automatically sent him on every payment date. When such debentures are registered as to principals only, coupons are attached. The holder must detach the coupons for interest payment and collect them as in the case of bearer bonds.

C. Secured Debentures - Debenture which creates a charge on the property of the company is a secured debenture. The charge may be floating or fixed. The floating charge is not attached to any particular asset of the company. But when the company goes into liquidation the charge becomes fixed. Fixed charge debentures are those where specific asset or group of assets is pledged as security. The details of these charges are to be mentioned in the trust deed.

D. Unsecured / Naked Debentures - These are not protected through any charge by any property or assets of the company. They are also known as naked debentures. Well established and credit worthy companies can issue such shares.

E. Redeemable Debentures - When the debentures are redeemable, the company has the right to call them before maturity. The debentures can be paid off before maturity, if the company can afford to do so. Redemption can also be brought about by issuing other securities less costly to the company in the place of the old ones.

F. Convertible Debentures - When an option is given to convert debentures into equity shares after a specific period, they are called as convertible debentures. Convertible debentures give the holders the right to convert them into equity shares on certain terms. They are entitled to a fixed income till the conversion option is exercised and would share the benefits associated with equity shares after the conversion. All the details about conversion terms, namely, conversion ratio, conversion premium / price and conversion timing are specified in the offer document / prospectus. Companies can issue Fully Convertible Debentures (FCDs) or Party Convertible Debentures (PCDs).

G. Non-convertible Debentures - If the company issues, the holders of such debentures can buy a specified number of shares from the company at a predetermined price. The option can be exercised only after a specified period.

H. Perpetual Debentures- If the debentures are issued subject to redemption on the happening of specified events which may not happen or an indefinite period, i.e. winding up, they are called perpetual debentures.

4. Innovative Debt Instruments - In order to improve the attractiveness of fixed income securities, namely - bonds and debentures, some new features have been added. As a result, a wide range of innovative debt securities have emerged in India, particularly, after the early nineties. Bonds are debt instruments that are issued by companies / governments to raise funds for financing their capital requirements. By purchasing a bond, an investor lends money for a fixed period of time at a predetermined interest (coupon) rate. Bond has fixed face value which is the amount to be returned to the investor upon maturity of the bond. During this period, the investors receive a regular payment of interest, semi-annually or annually, which is calculated as a certain percentage of the face value and known as a 'coupon payment.' Bonds can be issued at par, at discount or at premium. Both debentures and bonds mean the same. In Indian parlance, debentures are issued by corporate and bonds by government or semi-government bodies. But now, corporate are also issuing bonds which carry comparatively lower interest rates and preference in repayment at the time of winding up, 
comparing to debentures. The government, public sector units and corporate are the dominant issuers in the bond market. Bonds issued by corporate and the Government of India can be traded in the secondary market. The different types of bonds are discussed as below:

A. Zero Interest Bonds (ZIBs) - Also known as Zero Coupon Bonds (ZCBs) or Zero Interest Debentures (ZIDs), the instruments do not carry any explicit / coupon rate of interest. They are sold at a discount from their maturity value. The difference between the face value of the bond and the acquisition cost is the gain / return to the investors. The implicit rate of return / interest on such bonds can be computed by the equation: Acquiring price $=$ Maturity $($ Face $)$ Value $/(1+i)^{\mathrm{n}}$ where, $i=$ rate of interest per rupee per year and $n$ = maturity period (years).

B. Deep Discount Bond (DDB) - A Deep Discount Bond is a form of Zero Interest Bond (ZIB). It is issued at a deep / steep discount over its face value. It implies that the interest (coupon) rate is far less than the yield to maturity. The DDB appreciates to its face value over the maturity period. DDBs are being issued by the public financial institutions in India, namely - IDBI, SIDBI and so on.

C. Mortgage Bonds - This is the common type of bonds issued by the corporate. Mortgage bonds are secured by physical assets of the corporation such as their building or equipment.

D. Convertible Bonds - This type of bond allows the bond holder to convert their bonds into shares of stock of the issuing corporation. Conversion ratio (number of equity shares in lieu of a convertible bond) and the conversion price (determined at the time of conversion) are pre-specified at the time of bonds issue.

E. Step-Up Bonds - A bond that pays a lower coupon rate for an initial period which, then increases to a higher coupon rate.

F. Callable and Non-Callable Bonds - If a bond can be called (redeemed) prior to maturity, the bond is said to be callable. If a bond cannot be called prior to maturity, it is said to be non-callable. Beginning from 1992, when the Industrial Development Bank of India issued bonds with call features, several callable bonds have emerged in the country in the recent years. Call provisions provide flexibility to the company to redeem them prematurely. Generally, firms issue bonds at a presumably lower rate of interest when market conditions are favorable to redeem such bonds.

G. Option Bonds - In this type, the investors have the option to choose between cumulative or noncumulative bonds. In the case of cumulative bonds, interest is accumulated and is payable on maturity only. In non-cumulative type interest is paid periodically.

H. Bonds with Warrants - A warrant allows the holder to buy a number of equity shares at a prespecified price in future. Bonds are issued with warrants to make it more attractive.

I. Floating Rate Bonds (FRBs) - Floating rate bonds are bonds wherein the interest rate is not fixed and is linked to a benchmark rate such as interest on treasury bills, bank rate and maximum rate on term deposits. It is typically a certain percentage point higher than the benchmark rate. The price of FRBs tends to be fairly stable and close to par value in comparison to fixed interest bonds. They provide protection against inflation risk to investors, particularly in comparison to interest rates provided by banks and financial institutions.

J. Secured Premium Notes (SPNs) - The SPN is a secured debenture, redeemable at a premium over the face value / purchase price. It resembles to a ZIB. There is a lock-in-period for SPN, during which no interest is paid. The holder has the option to sell the SPN back to the issuing company, at par, after the lock-in-period. The redemption is made in installments. The SPN is a tradable instrument. Although the SPN is akin to a ZIB to the extent it has no coupon rate of interest (where the interest payment and principal repayment are spread over a period of some years), whereas in case of ZIBs the entire payment is made in lump sum on maturity.

5. Derivative instruments - Derivative is an instrument whose value is derived from the value of one or more underlying assets which can be commodities, precious metals, currency, bonds, stocks, stock indices, etc. Derivative instruments in Indian stock exchanges are Index Futures, Stock Futures, Options on Index and Options on Individual Stocks. At present on NSE, different Index Futures are Nifty Future, Bank Nifty Future, and CNX IT Future and different Index Options are Option on Nifty, Option on Bank Nifty and Option on CNX IT. Besides these, Stock Futures on specified individual stocks on NSE and on those specified stocks on NSE are allowed to 
trade. A brief description on each type of derivative instruments in Indian market is made as under:

A. Sensex Future and Nifty Future - Sensex Future in BSE is a financial derivative product enabling one to buy or sell underlying Sensex on a future date at a price decided by the market forces today. It is the first financial derivative product in India. The security name used for Sensex Future in BSE is BSX. On NSE, the similar type of index-based future is Nifty Future. The security name and ticker symbol used for Nifty Future is NFUTIDX NIFTY.

B. Stock Future - Stock Future is a financial derivative product where the underlying asset is an individual stock. It is also called Equity Future. This derivative product enables one to buy or sell the underlying stock on a future date at a price decided by the market forces today. The theoretical price of a future contract is sum of the current spot price and cost of carry. However, the actual price of futures contract very much depends upon the demand and supply of the underlying stock. Generally, the Futures prices are higher than the spot prices of the underlying stocks. Futures Price $=$ Spot price + Cost of Carry . Cost of Carry is the interest cost of a similar position in cash market and carried to maturity of the Futures contract less any dividend expected till the expiry of the contract. Example: Spot Price of Infosys = Rs. 2000; Interest Rate $=12 \%$ p.a. Futures Price of 1 month contract $=$ Rs. 2,000+ Rs. $(2,000 \times 0.12 \times 30 / 365)=$ Rs. $(2,000+20)=$ Rs. 2,020.

C. Stock Index - It is a financial derivative product where the underlying asset is the stock index of a particular stock exchange. This financial derivative product enables one to buy or sell Call Option or Put Option (to be exercised at a future date) on the underlying asset (i.e. Stock Index) at a premium decided by the market forces today. On NSE, currently among various Stock Index Options available for trading, Options on Nifty and Options on Nifty Junior are very popular. On BSE, the most commonly used Stock Index Option is Option on Sensex. A Stock Index Option gives an investor the right to buy or sell the value of an index which represents a group of stocks. Such Index Options are quoted with Strike Price and Premium per Option in Rupees along with paise. A Call Option gives the holder (buyer/one who is long Call), the right to buy specified quantity of the underlying asset at the strike price on or before expiration date in case of American style of Option. The seller (one who is short Call) however, has the obligation to sell the underlying asset if the buyer of the Call Option decides to exercise his Option to buy. Example: An investor buys One European Call Option of Infosys at the strike price of Rs. 2,000 at a premium of Rs. 100. If the market price of Infosys on the day of expiry is more than Rs. 2,000, the Option will be exercised. The investor will earn profits once the share price crosses Rs. 2,100 (, i.e., strike Price Rs. 2,000 + Premium Rs. 100). Suppose stock price on the expiry date is Rs. 2,300, the Option will be exercised and the investor will buy 1 share of Infosys from the seller of the Option at Rs. 2,000 and sell it in the market at Rs. 2,300 making a profit of Rs. 200 \{(Spot price - Strike price) - Premium $\}$. In another scenario, if at the time of expiry, stock price falls below Rs. 2,000, suppose it touches Rs. 1,800, the buyer of the Call Option will choose not to exercise his Option. In this case the investor loses the premium paid (i.e., Rs. 100), which shall be the profit earned by the seller of the Call Option. A Put Option gives the holder (buyer/one who is long Put), the right to sell specified quantity of the underlying asset at the strike price on or before the expiry date (in case of American style Option). The seller of the Put Option (one who is short Put) however, has the obligation to buy the underlying asset at the strike price if the buyer decides to exercise his Option to sell. Example: An investor buys one European Put Option of HPCL at the strike price of Rs. 300 , at a premium of Rs. 25. If the market price of HPCL, on the day of expiry is less than Rs. 300, the Option can be exercised as it is 'in the money'. The investor's Break Even Point (i.e., no profit no loss situation) is Rs. 275 (Strike Price - Premium paid). The investor will earn profit if the market falls below Rs. 275. Suppose stock price is Rs. 260, the buyer of the Put Option immediately buys HPCL share in the market@Rs. 260 and exercises his Option, selling the HPCL share at Rs. 300 to the Option writer thus making a net profit of Rs. 15 \{(Strike price - Spot price) - Premium paid . In another scenario, if at the time of expiry, market price of HPCL is Rs. 320, the buyer of the Put Option will choose not to exercise his Option to sell as he can sell in the market at a higher rate. In this case the investor loses the premium paid (i.e. Rs. 25), 
which shall be the profit earned by the seller of the Put Option.

D. Swaps - A swap is a derivative contract between two parties to exchange cash flows in the future according to a prearranged formula. They can be regarded as portfolios of forward contracts. Interest rate swaps and currency swaps are the most popular swap contracts which are traded over the counters between financial institutions. These contracts are not traded on exchanges. Retail investors generally do not trade in swaps.

E. Forward contract - A forward contract is an Over The Counter (OTC) customized agreement between two parties - a buyer and a seller to purchase or sell something at a later date at a price agreed upon today. Forward contracts, sometimes called forward commitments are very common in everyone life. Any type of contractual agreement that calls for the future purchase of a good or service at a price agreed upon today and without the right of cancellation is a forward contract.

6. Government instruments - The government, either central government, state government or local governments, such as, municipalities, metropolitan authorities, port trusts, development trusts, state electricity boards, public sector undertakings and other government agencies, viz. IDBI, SFCs, NABARD, SIDCs, etc. raises long term funds by issuing bonds. These bonds do not carry any risk and they are as good as government guarantees in regard to the payment of interest as well as repayment of principal money. These are also known as gilt-edged bonds.

7. Fixed Deposit - Fixed Deposit is that kind of bank account, where the amount of deposit is fixed for a specified period of time. All Commercial banks are given these opportunities to their customers for opening a fixed account in their bank. In a Fixed account, the amount of deposit is fixed, which means we cannot withdraw an unlimited amount from this account; therefore it is also called a Fixed Deposit. If an account holder wants to withdraw a small amount of money from their account, then he will require closing of the fixed deposit account. The main purpose of account holders to open this account is to earn interest money from their actual money, which is given by the banks during a specified period of time.

8. Hedge Fund - Hedge funds including fund of funds are unregistered private investment partnership, funds or pools that may invest and trade in many different markets, strategies and instruments (including securities, non securities and derivatives) and are not subject to the same regulatory requirements as mutual funds, including mutual fund requirements to provide certain periodic and standardized pricing and valuation information to investors. Hedge funds are sometime called as rich man's mutual funds.

9. Gold Exchange Trade funds - SEBI (Mutual Funds) Amendment Regulations dated January 24, 2006 permitted introduction of Gold Exchange Traded Fund schemes by Mutual Fund. Gold Exchange Traded Fund (GETF) schemes are permitted to invest primarily in Gold and Gold related instruments i.e. such instruments having gold as underlying as are specified by SEBI from time to time.

10. Foreign instruments - There are some instruments which are very much attractive to the investors in the global financial markets. These instruments are denominated in dollars. These instruments are mentioned as follows:

A. NRI bonds - NRI bonds are forex deposits raised from non-resident Indians at attractive rates for 35 years, with some lock-in and an implicit RBI guarantee. RBI issues NRI bonds to support the rupee and offset the slowdown in foreign portfolio investment (FPI) flows amid rising oil prices. The FPI inflows to India will be impacted by Chinese firms listing in global benchmark indices like MSCI. According to a Bank of America Merrill Lynch (BofAML) report, the listing in benchmark -indices will shift up to USD 100 billion to China market by 2019 .

B. ADR / GDR - Indian Capital Market was dominated mostly by Indian investors till early part of the 1990s. Since 1992, being integrated with global market, Indian Companies have been raising funds not only from the local markets and institutions but also from foreign markets as well in the form of ADRs (American Depository Receipts) and GDRs (Global Depository Receipts). These two instruments are collectively known as Euro Issues. This gives Indian Companies access to low cost funds but they have to adopt international accounting practices in order to approach the foreign markets.

C. IDRs - Indian Depository Receipts (IDRs) are the instruments denominated in Indian rupees in the form of depository receipts against the underlying equity of issuing company enabling foreign companies to raise funds from the Indian market. It is a positive step of government of India to 
integrate Indian capital market with the global capital markets in the era of globalization of economy.

\section{CONCLUSION}

Capital market refers to a type of financial market where individuals and institutions are trading in financial securities issued by governments and companies from time to time. Here the buyers and sellers of securities can enter to purchase and sell all types of securities like shares, debentures, bonds, etc. These capital market instruments play important role in Indian economy under the present scenario of globalization and liberalization. Many reform measures have been taken by the government of India after 1990s. Presently, Indian capital market is not only for Indian investors. It facilitates the internationalization of Indian economy by linking it with rest of the world. The lace of advance and vibrant capital market instruments can lead to under utilization of financial resources. The above list of capital market instruments is not exhaustive but inclusive. Other instruments may be created with the approval of capital market regulator depending upon the requirement of the economy and industry.

\section{REFERENCES}

Books:

1. Sarkhel Jaydeb and Gupta Arindam (2002), Capital Market: Theory and Institutions, Book Syndicate Private Ltd.

2. Das Subhash Chandra (2015), the Financial System in India: Markets, Instruments, Institutions, Services and Regulation, PHI Learning Private Limited, Delhi.

3. Bhaskara, P. Vijaya \& Mahapatra, B. (2003), Derivatives Simplified: An Introduction to Risk Management, Sage Publication, New Delhi

4. Majumdar, A. K. and Kapoor. G. K. (2005), Students' Guide To Company Law, Taxmann Publications (P) Ltd., New Delhi
5. Vashisht, A. K. \& Gupta, R. K. (2005), Investment Management and Stock Market, Deep \& Deep Publication Pvt. Ltd. New Delhi

\section{Articles in Journals:}

1. Vashistha, S. D., The Secondary Capital Market: Some Important Aspects, The Indian Journal of Commerce, Conference Issue (2001), Vol. 54 No. 4

2. Vijaysingh Thakur Devendrasingh, Emerging Issues in Capital Market, The Indian Journal of Commerce, Conference Issue (2001), Vol. 54 No. 4

3. Thakur, P. C. and J. Raghakardar Pal Singh, Reflections on the Changing Scenario of the Indian Stock Exchanges, The Indian Journal of Commerce, Conference Issue (2001), Vol. 54 No. 4

\section{Websites:}

1. https://financeaccountingsimplified.com/tag/capita 1-market-instruments/

2. https://www.slideshare.net/kartikganga/capitalmarket-instruments

3. https://www.slideshare.net/Nasaso90/capitalmarket-instrument

4. https://www.slideshare.net/.../instruments-ofmoney-market-and-capital-market

5. https://www.businessmenmanagementideas.com

6. www.swlearning.com/finance/burton/fmi/powerpo int/ch03.ppt

7. www.inc.com/encyclopedia

8. www.martinfowler.com

9. www.financenectar.com/capital-marketinstruments-in-india/

10. www.lexicon.ft.com

11. www.anilrazb.worldpress.com

12. Www.wikipedia.org

13. www.businessjargons.com 